\title{
Pengaruh Assertiveness Training terhadap Konsep Diri Pada Peserta Didik Kelas X di SMK N 5 Bandar Lampung Tahun Pelajaran 2015/2016
}

\author{
Defriyanto. Siti Masitoh
}

Fakultas Tarbiyah dan Keguruan. IAIN Raden Intan Lampung

Diterima: 18 Januari 2016. Disetujui: 28 Februari 2016. Dipublikasikan: Mei 2016

\begin{abstract}
Abstrak: Konsep diri sangat penting bagi kehidupan seseorang karna dengan adanya konsep diri maka seseorang dapat mengontrol prilakunya dan dapat mengetahui mana yang baik dan buruk baginya. Adapun masalah konsep diri peserta didik dapat dikategorikan masalah pribadi sosial. karena peserta didik yang memiliki konsep diri negatif tidak hanya berpengaruh buruk terhadap perkembangan dirinya. akan tetapi juga berpengaruh pada reaksi terhadap situasi dilingkungannya. Assertiveness Training merupakan latihan keterampilan sosial yang diberikan kepada individu yang diganggu kecemasan. tidak mampu mempertahankan hak-haknya. terlalu lemah. membiarkan orang lain merongrong dirinya. serta tidak mampu mengekspresikan amarahnya dengan benar dan cepat tersinggung. Adapun tujuan dalam penelitian ini adalah untuk mengetahui adakah pengaruh assertiveness training terhadap konsep diri pada peserta didik. Jenis penelitian ini adalah penelitian eksperimen. menurut sifatnya penelitian ini bersifat deskriptif kuwantitatif. Sumber data dalam penelitian ini adalah peserta didik kelas X. Teknik yang digunakan dalam pengumpulan data yaitu teknik kuesioner. observasi. interview dan dokumentasi. Selanjutnya langkah yang digunakan dalam menganalisa data pertama editing. coding. data entri. dan cleaning kemudian untuk mengetahui keberhasilan eksperimen dengan menggukan uji $\mathrm{t}$ dan dengan bantuan program SPSS. Hasil penelitian diperoleh bahwa. konsep diri peserta didik kelas X di SMK negeri 5 Bandar Lampung dapat dipengaruhi dengan konseling asertivenes training.hal itu dapat terlihat dengan: adanya perubahan sikap dari sebelum dan setelah di berikan perlakuan dengan konseling asertivenes traing. dan berdasarkan uji pengaruh dengan uji $\mathrm{t}$ di dapat $\mathrm{t}$ hitung $>$ dari $\mathrm{t}$ tabel atau (4.004>2) yang artinya adanya pengaruh konseling asertivenes terhadap konsep diri peserta didik.
\end{abstract}

Kata Kunci: konseling asertiveness training dan konsep diri

\section{Pendahuluan}

Layanan bimbingan dan konseling yang terdapat di sekolah memiliki peranan yang penting dalam pengembangan diri siswa. khususnya konsep diri siswa. Sesuai dengan fungsi bimbingan dan konseling yaitu pemahaman. pencegahan. pengentasan. pemeliharaan dan pengembangan. Dalam bimbingan dan konseling juga terdapat empat bidang bimbingan (pribadi. sosial. belajar dan karier) dan tujuh layanan (layanan orientasi. informasi. penyaluran dan penempatan. penguasaan konten. konseling perorangan. konseling kelompok dan bimbingan kelompok) yang kesemua unsur dalam bimbingan dan konseling tersebut dapat memfasilitasi berkembangnya karakteristik pribadi siswa secara optimal terutama dalam pengembangan dan peningkatan konsep diri kearah yang positif pada siswa.

Pada prinsipnya sebagai makhluk sosial. antara individu yang satu dengan yang lainnya pasti membutuhkan kerjasama. Ketergantungan manusia satu dengan yang lain merupakan suatu gejala yang wajar dalam kehidupan. Dalam hubungan tersebut komunikasi merupakan salah satu komponen yang penting. Corak komunikasi akan banyak ditentukan oleh latar belakang orang yang berkomunikasi. seperti kebiasaan dan kepribadian. Agar komunikasi berlangsung secara efektif seseorang perlu memiliki kemampuan asertif. Kemampuan asertif adalah kemampuan untuk mengungkapkan perasaan seseorang dan menegaskan hak- hak seseorang tetap menghargai perasaan dan hak orang lain. Kemampuan Asertif disintetiskan menjadi lima aspek yaitu aspek ketegasan. tanggung jawab. percaya diri. kejujuran.dan menghargai orang lain. 
Dalam hubungan interpersonal. perilaku seseorang terhadap orang lain dapat dikelompokkan menjadi perilaku submisif. perilaku agresif dan perilaku asertif. Submisif berasal dari bahasa inggris yaitu submissive yang berarti bersikap tunduk. berhikmat. bersikap patuh. Jadi. perilaku submisif adalah perilaku yang selalu tunduk. menerima apa adanya. kurang bisa menyatakan kebutuhan. perasaan. nilai dan pemikiran sendiri. tidak bisa menolak dan membiarkan kebutuhan. pendapat. pikiran. penilaian orang lain mendominasi pendapat. pikiran dan penilaian dirinya. walaupun sebenarnya tidak sesuai dengan apa yang dirasakan. yang penting tidak masalah bagi orang lain. Akibat dari perilaku submisif. individu tesebut kurang berani mengambil suatu keputusan. menghindari konflik. takut disalahkan. sehingga orang lain memberikan respon negatif terhadap dirinya.

Bimbingan kelompok merupakan suatu upaya bimbingan kepada individu melalui kelompok dengan memanfaatkan dinamika kelompok dalam mencapai tujuan bimbingan kelompok. Berdasarkan pengertian tersebut. jelas bahwa layanan bimbingan kelompok menggunakan teknik Assertiveness Training merupakan usaha pemberian bantuan kepada siswa dengan memanfaatkan dinamika kelompok. Melalui dinamika kelompok setiap anggota kelompok diharapkan mampu mengembangkan dirinya dalam hubungannya dengan orang lain. Selain itu melalui dinamika kelompok masing- masing anggota kelompok akan berkontribusi baik secara langsung maupun tidak langsung dalam pemecahan masalah yang ada. Selain itu. anggota kelompok dapat saling memberikan pendapat. saran. tanggapan dan penilaian terhadap anggota kelompok yang lain. Melalui interaksi tersebut dapat membantu anggota kelompok untuk dapat lebih memahami diri dan orang lain. Untuk itu. layanan bimbingan kelompok merupakan salah satu jenis layanan dalam bimbingan dan konseling yang dianggap tepat untuk mengubah konsep diri negatif.

Dengan demikian. diharapkan layanan bimbingan kelompok dapat digunakan dalam mengubah konsep diri negatif menjadi konsep diri positif pada siswa. Seperti yang telah dijelaskan sebelumnya bahwa konsep diri terbentuk dari adanya interaksi antara individu dengan orang lain dengan interaksi yang terjadi antara anggota kelompok dalam bimbingan kelompok nantinya diharapkan dapat berdampak positif bagi siswa dalam penciptaan gambaran diri atau konsep diri siswa yang mencakup pengetahuan diri. pemahaman diri. penerimaan diri. penilaian diri dan harapan-harapan terhadap diri. Sehingga penulis tertarik mengangkat permasalahan ini dengan menggunakan tekhik assertiveness training agar percaya diri seseorang dapat meningkat.

Berdasarkan paparan di atas. maka penulis akan melakukan penelitian dengan judul "Pengaruh Assertiveness Training Terhadap Konsep Diri Pada Kelas X di SMK Negeri 5 Bandar Lampung Tahun Pelajaran 2015/2016.

\section{A. Konsep Diri}

1. Pengertian Konsep Diri

Sejak kecil individu telah dipengaruhi dan dibentuk dengan berbagai pengalaman yang dijumpai dalam hubungannya dengan individu lain. maupun yang didapatkan dalam peristiwa yang dialami dalam hidupnya. Berdasarkan pengalaman individu tersebut. dapat membuat dirinya memandang diri lebih baik atau lebih buruk. Cara pandang individu terhadap dirinya akan membentuk suatu konsep tentang diri sendiri atau lebih dikenal dengan sebutan konsep diri.

Pendapat Burns yang dikutip Desmita mengatakan Konsep diri adalah hubungan antara sikap dan keyakinan tentang diri kita sendiri. Sedangkan menurut Atwater yang dikutip Desmita menyebutkan bahwa konsep diri adalah keseluruhan gambaran diri yang meliputi persepsi seseorang tentang diri perasaan. keyakinan dan nilai- nilai yang berhubungan dengan dirinyaSelanjutnya. atwater mengidentifikasi konsep diri atas tiga bentuk. Pertama. body image. kesadaran tentang tubuhnya yaitu bagaimana seseorang 
melihat dirinya sendiri. Kedua. ideal self yaitu bagaimana cita-cita dan harapan-harapan seseorang mengenai dirinya. Ketiga. social self. yaitu bagaimana orang lain melihat dirinya.

Terbentuknya konsep diri seorang individu merupakan hasil dari interaksi individu dengan orang lain. konsep diri sebagai perasaan. pandangan dan penilaian individu mengenai dirinya yang didapat dari hasil interaksi dengan lingkungan sekitarnya. William H. Fitts yang dikutip Agustiani mengemukakan bahwa konsep diri merupakan aspek penting dalam diri seseorang. karena konsep diri seseorang merupakan kerangka acuan (frame of reference) dalam berinteraksi dengan lingkungan. Pendapat dari Fitts tersebut memiliki definisi yang berbeda mengenai konsep diri. Fitts lebih menekankan bahwa konsep diri yang dimiliki seorang individu akan menjadi patokan atau pedoman bagi individu dalam bersikap dan berperilaku dalam berinteraksi dengan orang lain. Berdasarkan uraian di atas dapat disimpulkan bahwa konsep diri adalah gagasan tentang diri sendiri yang mencakup keyakinan. pandangan dan penilaian seseorang terhadap dirinya sendiri.

2. Langkah-langkah yang Dapat Ditempuh dalam Konsep Diri Antara Lain:

a. Bersikap objektif dalam mengenai diri sendiri

Tidak mengabaikan pengalaman poisitif atau pun keberhasilan sekecil apapun yang pernah di capai. carilah cara dan kesempatan untuk mengembangkan talenta jangan terlalu beraharap bahawa diri kita dapat membahagiakan semua orang atau melakukan segala sesuatu secara sekaligus.

b. Hargailah diri sendiri

Hargailah diri sendiri dengan melihat kebaikan yang ada dalam diri sehingga kita mampu melihat hal baik yang ada dalam diri orang lain secara positif.

c. Jangan memusuhi diri sendiri

Memerangi diri sendiri adalah sesuatu hal yang melelahkan karena merupakan pertanda bahwa ada permusuhan dan peperangan antara harapan ideal dengan kenyataan diri yang sejati akibatnya akan timbul kelelahan mental dan rasa prustasi yang dalam yang mengakibatkan makin lemahnya konsep diri.

d. Berpikir positif dan rasional

Kendalikan pikiran kita ketika mulai menyesatkan jiwa dan raga.

3. Aspek-aspek Konsep Diri

Konsep diri pada seorang individu terdiri dari beberapa aspek atau komponen. Konsep diri terbentuk dari dua komponen yaitu komponen kognitif dan komponen afektif. Komponen kognitif merupakan pengetahuan individu tentang dirinya. Komponen kognitif merupakan penjelasan dari siapa saya yang akan membuat gambaran objektif tentang diri saya (the picture about my self) serta menciptakan citra diri (self image). Sedangkan komponen afektif merupakan penilaian individu terhadap dirinya. Penilaian tersebut akan membentuk penerimaan diri (self-acceptance) dan harga diri (self-esteem) pada individu. Jadi komponen afektif merupakan gambaran subjektif seorang individu tentang dirinya sendiri.

Sedangkan konsep diri menurut Calhaoun dan Acocella yang dikutip Nur Ghufron dan Rini Risnawita memiliki tiga aspek yaitu pengetahuan. pengharapan dan penilaian terhadap diri. Aspek pertama. pengetahuan individu mengenai diri dan gambarannya. Individu yang bersangkutan mendapat informasi mengenai keadaan dirinya seperti nama. usia. jenis kelamin. suku bangsa dan sebagainya. Aspek kedua. harapan individu dimasa mendatang yang disebut juga diri ideal yaitu kekuatan yang mendorong individu menuju kemasa depan. Aspek ketiga. penilaian terhadap diri sendiri yang merupakan perbandingan antara pengharapan diri dengan standar diri yang akan menghasilkan harga diri (self esteem). 
Menurut Hurlock yang dikutip Nur Ghufron dan Rini Risnawita mengemukakan bahwa konsep diri memiliki dua aspek yaitu fisik dan psikologis. Aspek fisik meliputi sejumlah konsep yang dimiliki individu mengenai penampilan kesesuaian dengan jenis kelamin arti penting tubuh dan perasaan gengsi dihadapan orang lain yang disebabkan oleh keadaan fisiknya. Berdasarkan penjelasan tersebut hal penting yang berkaitan dengan keadaan fisik adalah daya tarik dan penampilan tubuh dihadapan orang lain. Individu dengan penampilan yang menarik cenderung mendapatkan sikap sosial yang menyenangkan dan penerimaan sosial dari lingkungan sekitar yang akan menimbulkan hal yang positif bagi individu tersebut.

Sedangkan aspek psikologis meliputi penilaian individu terhadap keadaan psikis dirinya. seperti rasa percaya diri. harga diri. serta kemampuan dan ketidakmampuannya.

Sebagai contoh penilaian mengenai kemampuan dan ketidakmampuan diri akan mempengaruhi rasa percaya diri dan harga dirinya. Individu yang merasa mampu akan mengalami peningkatan rasa percaya diri dan harga diri. sedangkan individu dengan perasaan tidak mampu akan merasa rendah diri sehingga cenderung terjadi penurunan harga diri. Dari pendapat beberapa ahli yang telah dijelaskan di atas dapat disimpulkan bahwa aspek- aspek konsep diri adalah:

Pertama aspek kognitif. Aspek ini mencakup pengetahuan individu tentang dirinya sendiri yang didasarkan pada bukti-bukti objektif. Misalnya penegtahuan yang berhubungan dengan penampilan fisik. seperti usia. jenis kelamin. warna kulit. berat badan. tinggi badan. kemampuan fisik. kondisi alat indra dan sebagainya. Pengetahuan yang berhubungan dengan diri psikis. seperti karakter diri. bakat. minat. kemampuan akademik. kecerdasan. motivasi. kecemasan dan sebagainya. Pengetahuan tentang diri sosial seperti: hubungan individu dengan teman- teman sebaya dan masyarakat. hubungan dengan orang tua. guru dan orang dewasa lainnya.

Kedua. aspek persepsi atau cara pandang individu memahami hal-hal yang diketahuinya tentang fisiknya. individu memahami tentang hal-hal yang berhubungan dengan diri psikisnya. Demikian pula individu memahami dirinya dalam kaitannya dengan reaksinya dengan orang lain.

Ketiga. aspek penilaian. seperti individu menilai penampilan fisiknya. apakah ia menerima atau menolak dirinya. apakah ia memandang dirinya cantik atau jelek. Penilaian yang berhubungan dengan diri psikis seperti: bagaimana individu menilai karakter yang dimilikinya. kemampuan intelektualnya. prestasi akademiknya. minatnya dan sebagainya. Penilaian yang berhubungan dengan diri sosial seperti: apakah individu merasa memiliki harga diri atau tidak. merasa diterima orang lain atau tidak. merasa disukai atau dibenci orang lain dan sebagainya.

Keempat. aspek harapan. yang dimaksud dengan aspek harapan adalah apakah individu mempunyai cita-cita atau tidak bagi masa depannya dan harapan-harapan akan menjadi apa dirinya dimasa mendatang. Secara singkat bahwa konsep diri meliputi apa yang kita ketahui tentang diri kita. bagaimana kita mempersepsikannya. kemudian menilainya dan apa saja yang diharapkan dari diri kita dimasa mendatang.

\section{B. Teknik Assertiveness Training}

1. Pengertian Assertiveness Training

Perilaku asertif merupakan terjemahan dari istilah assertiveness atau assertion yang artinya titik tengah antara perilaku non asertif dan perilaku agresif. orang yang memiliki tingkah laku atau perilaku asertif orang yang berpendapat dari orientasi dari dalam. memiliki kepercayan diri yang baik. dapat mengungkapkan pendapat dan ekspresi yang sebenarnya tanpa rasa takut dan berkomunikasi dengan orang lain secara lancar. Sebaliknya orang yang kurang asertif adalah mereka yang memiliki ciri terlalu mudah mengalah atau lemah. mudah 
tersinggung. cemas. kurang yakin pada diri sendiri. sukar mengadakan komunikasi dengan orang lain dan tidak bebas mengemukakan masalah atau hal yang telah dikemukakan.

Sofyan S. Willis menjelaskan bahwa assertiveness training merupakan teknik dalam konseling behavioral yang menitikberatkan pada kasus yang mengalami kesulitan dalam perasaan yang tidak sesuai dalam menyatakannya. Assertiveness Training adalah suatu teknik untuk membantu klien dalam hal-hal yaitu tidak dapat menyatakan kemarahan atau kejengkelannya. mereka yang sopan berlebihan dan membiarkan orang lain mengambil keuntungan padanya. mereka yang mengalami kesulitan berkata "tidak". mereka yang sukar menyatakan cinta dan respon positif lainnya dan mereka yang merasakan tidak punya hak untuk menyatakan pendapat dan pikirannya.

Asertivitas merupakan perilaku antara perorangan atau hubungan interpersonal yang melibatkan aspek kejujuran dan keterbukaan pikiran serta perasaan. Dalam berperilaku asertif individu dituntut untuk jujur terhadap dirinya sendiri maupun orang lain dan jujur pula dalam mengekspresikan perasaan. tanpa ada maksud untuk memanipulasi. memanfaatkan ataupun merugikan orang lain.

Perilaku asertif adalah perilaku yang merefleksikan rasa percaya diri dan menghormati diri sendiri dan orang lain. hal ini sejalan dengan pengertian perilaku asertif yang dikemukakan oleh Alberti dan Emmons yaitu perilaku asertif meningkatkan kesetaraan dalam hubungan sesama manusia. yang memungkinkan kita untuk menunjukkan minat terbaik kita. berdiri sendiri tanpa harus merasa cemas. mengeekspresikan perasaan kita dengan jujur dan nyaman. melatih kepribadian kita yang sesungguhnya tanpa menolak kebenaran dari orang lain.

Maka dapat disimpulkan bahwa assertiveness training merupakan suatu teknik pemberian izin seseorang untuk belajar menyatakan perilaku yang sesuai dan efektif. sebelumnya dilarang oleh kecemasan yang salah atau suatu teknik yang digunakan untuk melatih individu bersikap asertif.

\section{Faktor Yang Mempengaruhi Tingkat Asertivitas Individu}

Tingkat asertifitas seseorang dipengaruhi oleh banyak faktor. Adapun faktor-faktor tersebut ialah mengetahui pikiran dan perasaan diri sendiri. berfikir secara realistik. berbicara tentang diri sendiri. berkomunikasi dengan yang di inginkan. bersikap positif terhadap orang lain. bebas membela diri. mampu berdikari. menggunakan jumlah kekuatan yang tepat. mengetahui batasan diri sendiri dan orang lain.

\section{Langkah-langkah Dalam Assertiveness Training}

Pelaksanaan assertiveness training memiliki beberapa langkah-langkah yang akan dilalui ketika pelaksanaan latihan. Pada umumnya teknik untuk melakukan latihan asertif. mendasarkan pada prosedur belajar dalam diri seseorang yang perlu diubah. diperbaiki dan diperbaharui. Ada beberapa langkah latihan asertif. yakni:

a. Identifikasi terhadap keadaan khusus yang menimbulkan persoalan pada klien.

b. Memeriksa apa yang dilakukan atau dipikirkan klien pada situasi tersebut. Pada tahap ini. akan diberikan juga materi tentang perbedaan perilaku agresif. asertif dan pasif.

c. Dipilih sesuatu situasi khusus klien melakukan permainan peran (role play) sesuai dengan apa yang ia perlihatkan.

d. Konselor memberikan umpan balik secara verbal. menekankan hal yang positif dan menunjukkan hal-hal yang tidak sesuai (tidak cocok. inadekuat) dengan sikap yang baik dan dengan cara yang tidak menghukum atau menyalahkan.

e. Konselor memperlihatkan model perilaku yang lebih diinginkan. pada tahap ini siswa melakukan role playing atau aturan main yang mendasari perilaku yang diinginkan. 
f. Diantara waktu-waktu pertemuan. konselor menyuruh klien melatih dalam imajinasinya. respon yang cocok pada beberapa keadaan.

g. Kepada mereka juga diminta menyertakan pernyataan diri yang terjadi selama melakukan imajinasi. Hasil apa yang dilakukan pasien atau klien. dibicarakan pada pertemuan berikutnya.

h. Konselor harus menentukan apakah klien sudah mampu memberikan respon yang sesuai dari dirinya sendiri secara efektif terhadap keadaan baru. baik dari laporan langsung yang diberikan maupun dari keterangan orang lain yang mengetahui keadaan pasien atau klien.

Berdasarkan uraian diatas. dapat disimpulkan bahwa assertiveness training merupakan terapi perilaku yang dirancang untuk mengembangkan keterampilan-keterampilan individu yang diganggu kecemasan dengan berbagai teknik yang ada agar individu tersebut dapat memiliki perilaku asertif yang diinginkan.

\section{Teknik Assertiveness Training dalam Meningkatkan konsep diri positif}

Assertiveness training merupakan rangkuman yang sistematis dari keterampilan. peraturan. konsep atau sikap yang dapat mengembangkan dan melatih kemampuan individu untuk menyampaikan dengan terus terang pikiran. perasaan. keinginan dan kebutuhannya dengan penuh percaya diri sehingga dapat berhubungan baik dengan lingkungan sosialnya.

Konsep diri adalah individu dapat mengenal tentang dirinya sendiri menyangkut perasaan. perilaku. pikiran dan bagaimana nantinya hal-hal tersebut berpengaruh terhadap interaksi dengan orang lain. Berdasarkan hal tersebut. maka untuk meningkatkan konsep diri yang positif dapat digunakan teknik assertiveness training.

Keefektifan teknik assertiveness training telah banyak dibuktikan dengan berbagai penelitian eksperimen seperti : Penelitian ini menekankan bahwa ada pengaruh penggunaan teknik assertiveness training dalam menanggulangi perilaku siswa yang berperilaku tidak percaya diri maupun menyimpang.

Seorang guru disekolah yang bisa menangani kemarahan yang membludak dari murid-muridnya yang terkenal sering ribut dan menganggu teman-temannya bahkan seorang anak tidak percaya diri akan kemampuannya di kelas. Metode tersebut dinamakan sebagai metode asertif karena menangani kemarahan anak dengan cara berempati padanya dan mengusahakan agar anak pun bisa berempati pada temannya bahkan dengan adanya assertiveness training. Assertiveness training ini yang dapat menangani perilaku negatif anak di kelas.

Dengan demikian Teknik assertiveness training dapat digunakan untuk peningkatan kepercayaan diri siswa sehingga menjadi konsep diri positif pada siswa semakin meningkat. Dalam penelitian ini dijelaskan bahwa siswa yang memiliki harga diri yang rendah akan ditingkatkan dengan penggunaan assertiveness training. sehingga jika harga dirinya meningkat maka konsep diri positif siswa meningkat.

Dari uraian tersebut di atas jelas bahwa penggunaan teknik Assertiveness Training sangat berpengaruh dapat meningkatkan konsep diri yang positif sehingga akan membantu dalam mencapai perkembangan yang optimal.

\section{Kelebihan dan Kekurangan Assertiveness Training}

1. Kelebihan pelatihan asertif ini akan tampak pada:

a. Pelaksanaannya yang cukup sederhana.

b. Penerapannya dikombinasikan dengan beberapa pelatihan seperti relaksasi. ketika individu lelah dan jenuh dalam berlatiih. kita dapat melakukan relaksasi supaya menyegarkan individu itu kembali. Pelatihannya juga bisa menerapkan teknik modeling. misalnya konselor mencontohkan sikap asertif langsung dihadapan 
konseli. Selain itu juga dapat dilaksanakan melalui kursi kosong. misalnya setelah konseli mengangankan tentang apa yang hendak diutarakan. ia langsung mengutarakannya di depan kursi yang seolah-olah dikursi itu ada orang yang dimaksud oleh konseli.

b. Pelatihan ini dapat mengubah perilaku individu secara langsung melalui perasaan dan sikapnya.

c. Disamping dapat dilaksanakan secara perorangan juga dapat dilaksanakan dalam kelompok. Melalui latihan-latihan tersebut individu diharapkan mampu menghilangkan kecemasan- kecemasan yang ada pada dirinya. mampu berfikir relistis terhadap konsekuensi atas keputusan yang diambilnya serta yang paling penting adalah menerapkannya dalam kehidupan ataupun situasi yang nyata.

2. Kelemahan. pelatihan asertif ini akan tampak pada :

a. Meskipun sederhana namun membutuhkan waktu yang tidak sedikit. ini juga tergantung dari kemampuan individu itu sendiri.

b. Bagi konselor yang kurang dapat mengkombinasikannya dengan teknik lainnya. pelatihan asertif ini kurang dapat berjalan dengan baik atau bahkan akan membuat jenuh dan bosan konseli/peserta atau juga membutuhkan waktu yang cukup lama.

\section{Metode Penelitian}

Menurut kamus besar bahasa indonesia. penelitian adalah kegiatan pengumpulan. pengolahan. analisa dan penyajian data dilakukan secara sistematis dan objektif untuk memecahkan suatau persoalan atau menguji suatu hipotesa untuk mengembangkan prinsipprinsip umum. Metode merupakan alat bantu yang di gunakan untuk memperlancar pelaksanaan penelitian. Secara umum metode penelitian diartikan sebagai cara ilmiah untuk mendapatkan data dengan tujuan dan kegunaan tertentu.

Berdasarkan pendapat tersebut dapat dipahami bahwa metode penelitian adalah tata cara dalam melaksanakan penelitian dengan melakukan berbagai upaya untuk mencari fakta serta mencapai tujuan yang ingin dicapai dalam kegiatan penelitian tersebut. Dalam penelitian ini peneliti menggunakan jenis penelitian kuantitatif data berupa angka-angka dan analisis menggunakan statistik. Metode penelitian menggunakan metode eksperimen. metode eksperimen adalah metode penelitian yang digunakan untuk mencari pengaruh perlakuan tertentu terhadap yang lain dalam kondisi yang terkendalikan. Desain yang digunakan dalam penelitian ini adalah pre-experimental design dengan pola one-group pretest-posttest design. Pada desain ini terdapat pretes sebelum diberi perlakuan. Dengan demikian hasil perlakuan dapat diketahui lebih akurat. karena dapat membandingkan dengan keadaan sebelum diberi perlakuan.

\section{Hasil dan Pembahasan}

Penelitian ini dilaksanakan di SMK Negeri 5 Bandar Lampung. pengumpulan data dalam penelitian ini diperoleh dengan cara melakukan eksperimen. Desain eksperimen yang digunakan adalah desain kelompok tunggal pretest dan posttest (One Group Pretest Posttest Design). Eksperimen dilaksanakan terhadap satu kelompok tanpa kelompok pembanding dengan memberikan tes awal dan tes akhir kepada subjek penelitian.

Langkah pertama dalam pengambilan data adalah melakukan tes awal (pretest). Tes ini dilakukan untuk mengetahui skor siswa sebelum diberi perlakuan (treatment). Setelah dilakukan tes awal. langkah selanjutnya yaitu memberikan perlakuan dengan konseling assertiveness training terhadap konsep diri peserta didik. Setelah perlakuan selesai dilakukan. selanjutnya dilakukan tes akhir (posttest) guna mengetahui ada atau tidaknya pengaruh dari 
layanan konseling assertiveness training. Populasi dalam penelitian ini adalah peserta didik kelas X SMK Negeri 5 Bandar Lampung.

1. Konsep diri peserta didik kelas X SMK Negeri 5 Bandar Lampung.

Berdasarkan hasil penyebaran angket terhadap konsep diri pada 22 orang peserta didik dengan item soal 50 soal. diperoleh perhitungan dengan bantuan program SPSS dapat dilihat pada tabel di bawah ini:

Tabel 4. Descriptive Statistics Hasil Pretest

\begin{tabular}{cccccccccc}
\hline & $\mathrm{N}$ & Range & Minimum & Maximum & Mean & Median & Mode & Std. & Variance \\
\cline { 2 - 9 } $\mathrm{Y}$ & 22 & 57 & 149 & 206 & 168.82 & 179 & 179.50 & 14.208 & 201.870 \\
\hline $\begin{array}{c}\text { Valid N } \\
\text { (listwise) }\end{array}$ & 22 & & & & & & & & \\
\hline
\end{tabular}

Berdasarkan tabel di atas dapat dipahami bahwa dengan $\mathrm{N}$ sebesar 22. dan $\mathrm{R}$ sebesar 57. serta nilai MAX sebesar 206 dan nilai MIN sebesar149 dengan SD sebesar 14.208. serta $\mathrm{V}$ pada 201.870. dengan diketahuinya nilai MAX dan nilai MIN maka konsep diri peserta didik dikategorikan kedalam tiga kategori sebagaiman tabel berikut ini:

Tabel 5. Gambaran Umum Konsep diri Peserta didik kelas X SMK Negeri 5 Bandar Lampung

\begin{tabular}{lccc}
\hline Kategori & Rentang & $\sum$ & Persentase \\
\hline Tinggi & $183-206$ & 3 & $14 \%$ \\
\hline Sedang & $155-183$ & 14 & $63 \%$ \\
\hline Rendah & $149-155$ & 5 & $23 \%$ \\
\hline \multicolumn{2}{c}{ Jumlah } & 22 & $100 \%$ \\
\hline
\end{tabular}

Tabel di atas menyatakan bahwa gambaran konsep diri peserta didik kelas X SMK Negeri 5 Bandar Lampung. terdapat sebanyak 3 peserta didik (14\%) berada pada kategori tinggi. konsep diri peserta didik pada kategori sedang sebanyak 14 orang peserta didik $(63 \%)$ dan kategori rendah sebanyak 5 orang peserta didik (23\%) sehingga dapat digambarkan sebagai berikut:

Gambar 2. Diagram Konsep Diri Peserta Didik

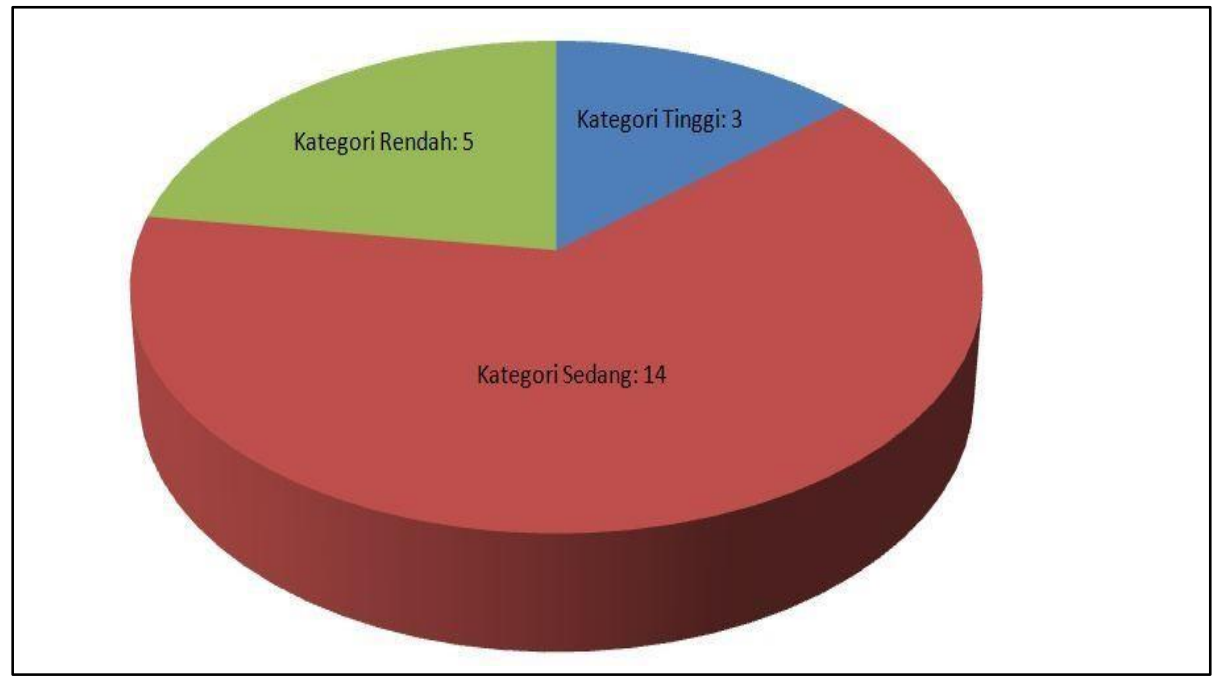

Berdasarkan diagram. 2 di atas terlihat bahwa konsep diri peserta didik di SMK Negeri 5 Bandar Lampung sebagian kecil berada pada kategori tinggi dalam kategori ini peserta didik telah menunjukkan konsep diri positif. namun lebih banyak terdapat peserta didik yang berada pada kategori sedang dalam kategori ini peserta didik telah memiliki 
konsep diri yang baik namun belum sepenuhnya. karena selain itu juga masih terdapat peserta didik yang berada pada kategori rendah dalam kategori ini peserta didik belum menunjukkan konsep diri yang baik. Berdasarkan tujuan diadakannya layanan konseling assertiveness training terhadap konsep diri peserta didik kelas X SMK Negeri 5 Bandar Lampung.

Selanjutnya gambaran konsep diri peserta didik dapat terlihat dari setiap aspek pendukungnya yaitu: (a) Peserta didik percaya dengan kemampuan yang dimiliki dalam mengatasi masalah. (b) Peserta didik menerima pujian tanpa ada rasa sombong. (c) Peserta didik yakin bisa dalam memperbaiki tingkah laku dalam dirinya dan (d) Peserta didik merasa setara dengan orang lain.

Dalam tahap ini peneliti menjelaskan dan memaparkan kegiatan konseling asrtivenes training yang akan dilakukan. tujuan dari tahap ini adalah untuk membantu peserta didik agar dapat mengidentifikasi dan menganalisa keadaan yang terjadi pada diri peserta didik (satuan layanan terlampir). Dalam peneliti atau konselor menjelaskan langkah-langkah pelaksanaan konseling asrtivenes training. Adapun langkah- langkah dalam tahap ini adalah :

a. Tahap persiapan

1) Konselor mengidentifikasi terhadap keadaan khusus yang menimbulkan persoalan pada klien.

2) Konselor memeriksa apa yang dilakukan atau dipikirkan klien pada situasi tersebut. dalam hal ini konselor mejelaskan mengenai teknik assertiveness training dan tujuan penggunaan asertivenes training merupakan kecendrungan untuk berpikir rasional dan irasional. Adapun tujuan dilaksanakannya konseling asertivenes training untuk memperbaiki dan merubah sikap. persepsi. cara berpikir. keyakinan serta pandanganpandangan klien yang irasional dan tidak logis menjadi menjadi pandangan yang rasional dan lugus agar klien dapat mengembangkan diri. meningkatkan konsep diri seoptimal mungkin melalui tingkah laku kognitif dan afektif yang positif.

3) Konselor memilih sesuatu situasi khusus klien melakukan permainan peran (role play) sesuai dengan apa yang ia perlihatkan.

4) Konselor mengadakan perkenalan. setiap konseli memperkenalan dirinya di hadapan orang lain (meskipun sudah saling mengenal). Konselor mengawali perkenalan dengan menyebutkan nama dan identitas lainnya kemudian dilanjutkan oleh konseli.

5) Konselor menjelaskan mengenai topik yang akan dibahas menegenai: kosep diri yang berkenaan dengan kepercayaan diri dalam mengatasi masalah. memperbaiki tingkah laku kearah yang lebih baik. dan tidak merasa rendah terhadap orang lain sehingga tidak menimbulkan kesombongan dengan apa yang dimiliki atau kemampuan yang dimiliki peserta didik. Diharapkan semua konseli dapat mengungkapkan masalahmasalah terkait topik permasalahan yang dibahas.

Berdasarkan pengamatan selama pelaksanaan tahap ini secara umum berjalan dengan lancar. hal ini terlihat dari antusias peserta didik yang dapat memahmi maksud dari kegiatan dan tujuan dari layanan konseling asertivenes training. namun pada awal tahap masih terdapat peserta didik malu-malu dan belum berani mengungkapkan permasalahannya terkait konsep diri dan penjelasan mengenai manfaat setelah melakukan kegiatan layanan konseling asertivenes training tersebut. sebagian besar peserta didik mulai dapat terbuka mengungkapkan kegiatan ini sebagai kegiatan berarti untuk meningkatkan konsep diri peserta didik. Tahap ini diakhiri dengan pembagian lembar persetujuan responden yang ditanda tangani peserta didik bersedia mengkuti tahap-tahap selanjutnya pada konseling asertivenes training. 
b. Tahap kegiatan

Pada tahap kegiatan ini konselor memulai kegiatan dengan menanyakan kepada konseli tentang topik yang akan dibahas secara bergantian dengan sukarela. Selanjutnya konselor menguraikan terlebih dahulu tentang topik yang akan dibahas dan setiap konseli diharapkan untuk dapat mengemukakan pada diri masing- masing apa yang dirasakan pada dirinya.

1) Sesi konseling pertemuan pertama

Pada pertemuan ini pokok bahasan yang akan dibahas yaitu mengenai konsep diri peserta didik. Konselor membangun suasana yang hangat dan serius serta tetap ceria. Pada pertemuan pertama topik pembahasan menggali konsep diri berkenaan dengan kepercayaan diri peserta didik dalam mengatasi masalah yang dihadapi oleh peserta didik. Dengan topik tersebut peserta didik diminta mendeskripsikan diri sendiri sejauh mana kepercayaan diri yang mereka miliki. hal ini dilakukan secara bergantian. pada tahap ini beberapa peserta didik antara lain; ANA. AAS. AP menceritakan masalah. Yangmana mereka menyadari akan keadaan diri sendiri. mereka kurang percaya diri dalam rangka menghadapi suatu masalah baik yang berasal dari pergaulan sesama teman atau yang berasal dari dalam keluarga. yang berakibat pada akhirnya mereka tidak ingin tahu dengan masalah yang sedang mereka hadapi. mereka beramsusmsi bahwa menurut mereka hal yang wajar jika mereka masih belum mempunyai keyakinan untuk bisa menyelesaikan permasalahan yang mereka hadapi. mereka juga berasumsi bahwa permasalahan yang mereka hadapi akan terselesaikan dengan sendirinya seiring waktu.

Berdasarkan cerita tersebut selanjutnya konselor memberikan waktu untuk konseli dalam memberikan masukan. Pada sesi pertama ANA memberikan masukan yaitu untuk dapat meninjau ulang apakah sikap yang mereka lakukan sesuai dan benar serta tepat karena menyikapi masalah dengan sikap yang telah di jelasakan di atas karena mereka menyadari hal itu dilakukan karena mereka kurang yakin untuk dapat menyelesaikan masalah yang mereka hadapi serta mereka juga mengungkapkan bahwa sikap demikian itu pada dasarnya bukan hal yang baik dalam menyelasikan masalah yang meraka hadapi. Selanjutnya konselor menyarankan untuk meminta solusi kepada teman yang dianggap bijak dalam setiap tindakan yang akan dilakukan apakah dapat merugikan atau sebaliknya.

Kemudian konselor mencoba untuk merasionalkan pemikiran atau keyakinankeyakinan konseli yaitu setiap permasalahan pasti ada solusi dan tidak untuk melakukan tindakan-tindakan yang bisa merugikan diri sendiri dan orang lain. Dengan berasumsi bahwa belum saatnya menyelesaikan masalah dengan kemampuan diri sendiri dan membiarkan masalah yang ada akan menimbulkan permasalahan baru terutama pada lingkungan sekolah. permainan. keluarga. Selanjutnya konselor meminta untuk setiap konseli mengkaji ulang setiap tindakan yang akan dilakukan misalkan untuk memikirkan dampak yang mungkin timbul baik dampak jangka pendek maupun jangka panjang dan orang lain juga belum tentu akan menganggap remeh yang mereka anggap meremahkan mereka. Kemudian konselor mengarahkan kepada konseli untuk dapat mendekatkan diri kepada sang pencipta. misalnya untuk lebih rajin dalam melaksanaka ibadah (shalat). Meskipun dalam pertemuan ini membutuhkan waktu yang lama namun konselor tetap mempertimbangkan efisien waktu.

2) Sesi konseling pertemuan kedua

Pertemuan kedua ini untuk melanjutkan pada pertemuan pertama denga topik konsep diri yang berkenaan dengan kemampuan diri peserta didik. Pada pertemuan ini anggota CR. DM. DDM. DF. menceritakan masalahnya pada saat ada masalah yang saya hadapi saya lebih baik main dari pada pusing dengan masalah yang ada. mendapat PR lebih baik saya mencontek punya teman karena kemampuan saya jauh dari teman saya dia lebih pinter dari saya. 
Berdasarkan pendapat yang telah disampaikan oleh konseli konselor melihat bahwa harus melakukan pembenahan terhadap pemikiran irassional konseli agar memiliki pemikiran atau keyakinan-keyakinan yang rasional. Selanajutnya konselor memberikan masukan agar dapat merubah keyakinan yang irrasional menjadi rasional bahwa tindakan yang mereka lakukan itu kurang tepat karena setiap permasalahan pasti ada jalan keluarnya dengan kita yakin dan percaya diri dengan kemampuan yang kita miliki dan setiap permasalahan bukanlah untuk dihindari namun permasalahan itu harus dihadapi agar dapat terselesaikan. serta janagn pernah merasa rendah terhadap dengan kemampuan diri sendiri bahwa pada dasarnya setiap orang memiliki kemampuan yang sama porsinya dengan apa yang dialaminya. konselor juga menekankan bahwa tindakan yang mereka lakukan akan berdampak buruk bagi dirinya ketik mereka hidup di tengah masyarakat. Pada pertemuan kedua dengan layanan yang kedua ini konseli terlihat lebih terbuka dan lebih aktif daripada pertemuan yang pertama. Secara keseluruhan pertemuan ini berjalan dengan baik dan lebih terarah. hal itu dapat terlihat dari konseli yang pada pertemuan pertama kurang menanggapi dengan positif sekarang berangsur-angsur membaik walaupun ada bbeberapa konseli yang masih kurang aktif. pertemuan kedua ini ada peningkatan dari pertemuan yang pertama.

3) Sesi konseling pertemuan ketiga

Pada pertemuan ini melanjutkan pertemuan sebelumnya namun pada pertemuan ketiga ini topik yang akan dibahas yaitu menghilangkan rasa sombong. Sesuai dengan materi yaitu untuk dapat mengendarlikan perasaan diri peserta didik agar tidak merasa sombong dan angkuh dengan apa yang dimiliki atau didapat terhadap orang lain yang merupakan salah satu dari ciri konsep diri positif peserta didik. Pada sesi ketiga ini IT. NA. OS. SS. menceritakan keadaan dirinya yaitu mereka merupakan orang yang merasa hanya mereka yang bisa melakukan apa yang mereka lakukan. dan tidak perlu untuk mengucapkan terima kasih terhadap orang yang telah membatu pekerjaan mereka. karena mereka berasumsi semua itu karena hasil dari kerja keras dan kesungguhan mereka dalam suatu pekerjaan atau kegiatan.

Selanjutnya RDL juga menganggap bahwa akan merasa seperti menjadi orang rendah dimata teman-teman apabila ia meminta pertolongan kepada orang lain. disitu juga ia merasa senang walaupun terkadang di jauhi oleh sebagian temanya karena sifat kesombonganya itu. Dari cerita tersebut selanjutnya konselor memberikan waktu kepada anggota kelompok untuk memberikan tanggapan untuk dapat menyelesaikan keyakinan yang irrasional tersebut bahwa dalam rangka menjalin hubungan sosisal denga orang lain tentunya dan pasti akan membutuhkan pertolongan ndari orang lain. dan merupakan bukanlah sifat rendah dikala kita menghormati bantuan orangatau pemberian orang dengan kita tidak bertingkah sombong dimata orang lain. dan juga tidak perlu merasa rendah jikala kita ingin meminta pertolongan kepada orang lain. karena sesungguhnya kita sebagai makhlik sosial sudah pasti akan membutuhkan bantuan dari orang lain dan tidaklah patut kita berlaku sombong atau membanggakan diri sendiri dengan kemapuan yang kita miliki. Pertemuan ini terlihat pada para konseli bersikap aktif dan antusias dalam membahas topik dengan begitu semangat. itu terlihat lebih hangat ketika salah seorang berbicara dengan berani untuk menceritakan masalah yang sedang dihadapinya.

4) Sesi konseling Pertemuan keempat

Pada pertemuan keempat ini konselor memberikan topik keyakinan dalam memperbaiki perilaku. dalam memperbaiki perilaku terdapat permasalahan yang terjadi pada para konseli. mereka sering mengalami dan mengaku bahwa yang menjadi faktor kesulitan untuk merubah suatu kebiasaan antara lain: karena adanya pengaruh dari teman yang membuat mereka melaukan tindakan atau bersifat yang terkadang menurut mereka itu salaha seperti dikala mendapat tugas dari sekolah dari pada pusing lebih baik bermain. karena menurut mereka pada akhirnya hal itu bisa diselesaikan pada saat jam sekolah hanya dengan 
mencontek teman yang telah selesai dan yang mereka anggap lebih baik dan pintar dari pada mereka. Pada tahap akhir ini juga konselor sedikit mereview tentang sesi konseling yang sebelumnya dan menekankan kembali pada konseli untuk dapat berpikir dan berkeyakinan yang rasional dan untuk menentukan komotmen langkah berikutnya dengan selalu meyakini kemampuan diri mereka dan dengan kemampuan yang mereka miliki agar tidak merasa rendah dan sombong dimata orang lain atau terhadap kemampuan orang lain.

\section{c. Tahap Pengakhiran}

Pada tahap pengakhiran ini konselor beserta konseli bersama- sama untuk menyimpulkan hasil dari beberapa pertemuan yang sudah dilakukan dan sekaligus mengemukakan pertemuan akan diakhiri. Adapun hasil kesimpulan dari 4 sesi konseling yang dilakukan yaitu untuk dapat meningkatkan konsep diri peserta didik yaitu dengan; 1) yakin/percaya dengan kemampuan diri sendiri. 2) menghilangkan sipat sombong dalam diri. 3) untuk dapat memperbaiki sikapyang ada dalam diri konseli. Dan tentunya utnuk dapat menjauhkan keyakinan- keyakinan yang irasional dan untuk berfikir yang rasional terhadap konsep diri yang positif. Kemudian konselor ataupun peneliti mempersilhkan kepada konseli untuk mengemukakan kesan-kesan dari layanan konseling asertivenes training yang telah dilakukan. Adapun kesan-kesan yang mereka kemukakan adalah sangat senang dan dapat merasakan manfaatnya bagi dirinya masing-masing khususnya pada awalnya berasumsi dan berkeyakinan yang irrasional atau kurang percaya diri sekarang secara perlahan dapat berfikir rasional atau berfikir posit dengn konsep diri yang mereka miliki. Meskipun pada awalnya konseli terlihat bingung. malu-malu dan takut namun pada akhirnya mereka dapat memhami dan antusias dalam mengikuti kegiantan tersebut dengan semangat dan terbuka. Diahir tahapan ini konselor meminta konseli atau peserta didik untuk menjawab peryataan yang berupa angket untuk mengukur hasil dari pada pemberian konseling dengan teknik asertivenes trainning terhadap konsep diri peserta didik

Tabel. 6 Hasil postest

\begin{tabular}{ccllllllll}
\hline & $\mathrm{N}$ & Range & Minimum & Maximum & Mean & Median & Mode & Std. & Variance \\
\cline { 2 - 9 } $\mathrm{Y}$ & 22 & 57 & 149 & 206 & 175.59 & 178 & 179.50 & 19.090 & 364.444 \\
\hline $\begin{array}{c}\text { Valid N } \\
\text { (listwise) }\end{array}$ & 22 & & & & & & & & \\
\hline
\end{tabular}

Berdasarkan tabel.5 di atas dapat dipahami bahwa dengan $\mathrm{N}$ sebesar 22. dan $\mathrm{R}$ sebesar 57. serta nilai MAX sebesar 206 dan nilai MIN sebesar149 dengan SD sebesar 19.090. serta $\mathrm{V}$ pada 364.444. dengan diketahuinya nilai MAX dan nilai MIN maka konsep diri peserta didik dikategorikan kedalam tiga kategori sebagaimana tabel berikut ini:

Tabel 7. Gambaran Konsep diri Peserta didik kelas X SMK Negeri 5 Bandar Lampung

\begin{tabular}{lccc}
\hline Kategori & Rentang & $\Gamma$ & Persentase \\
\hline Tinggi & $\mathrm{x}>183$ & 11 & $50 \%$ \\
\hline Sedang & $155-183$ & 6 & $27 \%$ \\
\hline Rendah & $\mathrm{x}<155$ & 5 & $23 \%$ \\
\hline \multicolumn{2}{c}{ Jumlah } & 23 & $100 \%$ \\
\hline
\end{tabular}

Berdasarkan tabel.6 di atas menyatakan bahwa gambaran konsep diri peserta didik kelas X SMK Negeri 5 Bandar Lampung. terdapat sebanyak 11 peserta didik (50\%) berada pada kategori tinggi. konsep diri peserta didik pada kategori sedang sebanyak 6 orang peserta didik $(27 \%)$ dan kategori rendah sebanyak 5 orang peserta didik $(23 \%)$ 
Hasil Uji T Pengaruh Koseling Asertivenes Training terhadap Konsep Diri Peserta Didik Di SMK Negeri 5 Bandar Lampung.

Pengaruh koseling assertiveness training dalam meningkatkan konsep diri peserta didik dapt dilihat dari goin score sebelum dan sesudah pelaksanaan konseling asertivenes training. terlebih dahulu dilakukan uji t untuk mengetahui pengaruh koseling asertivenes training terhadap konsep diri peserta didik.

Uji Pengaruh koseling asertivenes training terhadap konsep diri peserta didik secara keseluruhan. Berdasarkan hipotesis yang diajukan dalam penelitian ini adalah:

$\mathrm{H}_{\mathrm{o}}=$ Tidak adanya pengaruh layanan konseling asertivenes training terhadap konsep diri peserta didik di SMK Negeri 5 Bandar Lampung.

$\mathrm{H}_{\mathrm{a}}=$ Adanya pengaruh layanan konseling asertivenes training terhadap konsep diri peserta didik di SMK Negeri 5 Bandar Lampung.

Berdasarkan hasil uji t pretest dan posttest terhadap konsep diri peserta didik didapat hasil sebagai berikut.

Tabel.8 Hasil Uji t Pretest dan Posttest Terhadap Konsep Diri Peserta Didik

\begin{tabular}{ccccc}
\hline & Mean & N & $\begin{array}{c}\text { Std. } \\
\text { Deviation }\end{array}$ & $\begin{array}{c}\text { Std. Error } \\
\text { Mean }\end{array}$ \\
\hline Pair 1 Pretest & 168.82 & 22 & 14.208 & 3.029 \\
\hline Postest & 175.59 & 22 & 19.090 & 4.070 \\
\hline
\end{tabular}

Pada tabel.7 di atas menunjukkan perbedaan rata-rata antara hasil pretest sebesar 168.82; dengan kasus yang dianalisis sebanyak N=22; Std.Daviation (simpangan baku = 14.208). dan rata-rata postest sebesar 175.59; kasus yang dianalisis sebanyak

$\mathrm{N}=22$; Std.Daviation (simpangan baku= 19.090). Kemudian setelah diketahui hasil dari perbandingan sebelum(pretest) dan sesudah (postest) diberikanya perlakuan dengan konseling asertivenes training terhadap konsep diri peserta didik. maka diketahui korelasi antara kedua variable $0_{1}$ dan $0_{2}$ pada tabel di bawah ini:

Tabel. 9 Correlations Preetest \& Postest

\begin{tabular}{ccccc} 
Pair 1 & N & Correlation & Sig. \\
\cline { 2 - 5 } Pretest & $\begin{array}{c}\text { Pretest \& } \\
\text { Postest }\end{array}$ & 22 & .928 & .000 \\
\hline
\end{tabular}

Berdasarkan hasil pada tabel.8 di atas menunjukkan besarnya korelasi antara sebelum dan sesudah diberikannya perlakuan konseling asertivenes terhadap konsep diri peserta didik sebesar yaitu 0.928 dengan taraf signifikansi 0.000 .

Berdasarkan dengan pengajuan hepotesis yang telah diajukan dan kaidah keputusan yang menyatakan jika $(\alpha=0.05 \leq$ Sig). maka Ho diterima dan Ha ditolak. dan sebaliknya jika $(\alpha=0.05 \geq S i g)$. maka Ha diterima dan Ho ditolak.

Berdasarkan hasil perhitungan dengan bantuan program SPSS maka didapat Sig sebesar 0.000. Ternyata $\alpha=0.05$ lebih besar dari nilai Sig atau $(\alpha=0.05 \geq 0.000)$ maka Ha diterima dan Ho ditolak. Artinya adanya pengaruh layanan konseling asertivenes training terhadap konsep diri peserta didik di SMK Negeri 5 Bandar Lampung.

Selanjutnya setelah diketahui penerimaan dari hipotesis yang di ajukan maka selanjutnya ilakukan perhitungan untuk mengetahui nilai

perbandingan $t_{\text {hitung }}$ dan $t_{\text {tabel }}$ dapat dilihat pada tabel berikut ini: 
Tabel 10. Hasil Uji t Variabel Konsep Diri Peserta Didik Secara Keseluruhan Paired Samples Test

\begin{tabular}{|c|c|c|c|c|c|c|c|c|c|}
\hline & & \multicolumn{5}{|c|}{ Paired Differences } & \multirow[b]{3}{*}{$\mathrm{t}$} & \multirow[b]{3}{*}{ df } & \multirow[b]{3}{*}{ Sig. (2-tailed) } \\
\hline & & \multirow[b]{2}{*}{ Mean } & \multirow{2}{*}{$\begin{array}{c}\text { Std. } \\
\text { Deviation }\end{array}$} & \multirow{2}{*}{$\begin{array}{c}\text { Std. Error } \\
\text { Mean }\end{array}$} & \multicolumn{2}{|c|}{$\begin{array}{c}95 \% \text { Confidence Interval of } \\
\text { the Difference }\end{array}$} & & & \\
\hline & & & & & Lower & Upper & & & \\
\hline Pair 1 & Preetest-Postest & -6.773 & 7.934 & 1.692 & -10.290 & -3.255 & 4.004 & 21 & .001 \\
\hline
\end{tabular}

Dari tabel.9 di atas menunjukkan nilai t hitung sebesar 4.004 dengan tingkat Sig.(2tailed) $=0.001$ dengan $\mathrm{df}=\mathrm{N}-1=21-1=20$ sehingga nilai $\mathrm{t}_{\text {tabel }}=2.086$ pada taraf signifikansi $\alpha=0.05$. kemudian merujuk pada kaidah keputusan penerimaan hipotesis bahwa jika $t_{\text {hitung }} \geq t_{\text {tabel }}$ maka Ha diterima dan Ho ditolak. dan sebaliknya jika jika $t_{\text {hitung }} \leq t_{\text {tabel }}$ maka Ho diterima dan Ha ditolak.

Ternyata berdasarkan hasil perhitungan dan setelah dibandingkan didapat $t_{\text {hitung }}>t_{\text {tabel }}$ atau $4.004>2.086$ maka Ha diterima dan Ho ditolak. Jadi. ada perbedaan rata-rata nilai tes antara sebelum dan sesudah diberikan perlakuan. dari hasil perhitungan tersebut juga dapat diketahui bahwa adanya pengarauh layanan bimbingan konseling asertivenes training terhadap konsep diri peserta didik di SMK Negeri 5 Bandar Lampung.

\section{Perbandingan hasil nilai pretes dan postest.}

Berdasarkan hasil penelitian yang telah dilakukan sebelum di berikan perlakuan dengan konseling asertivenes training menunjukan bahwa konsep diri peserta didik kelas $\mathrm{X}$ SMK Negeri 5 Bandar Lampung berada pada kategori sedang namun masih terdapat peserta didik yang berada pada kategori sedang dengan 14 (63\%) dari 22 berada pada katagori sedang. dan 5 (23\%) peserta didik berada pada katagori rendah. kemudian 3 (14\%) peserta didik berada pada katagori tinggi. Sehingga berdasarkan data yang telah di peroleh tersebut konselor bereksperiment dengan memperbaiki konsep diri peserta didik dengan menggunaka konseling Asertivenes training terhadap konsep diri peserta didik. dalam rangka pemberian tindakan mengacu pada indikator yang telah diungkapkan sebelumnya.

Selanjutnya setelah pemberian tindakan maka konselor melakukan pengujian konsep diri peserta didik dengan melakukan penilai akhir yangmana hasilnya didapat sebanyak $11(50 \%)$ peserta didik berada pada kategori tinggi. dan sebanyak $6(27 \%)$ peserta didik. dan sebanyak $5(23 \%)$ peserta didik.

\section{Pengruh Layanan Konseling Asertivenes training Self Management dalam Meningkatkan Displinan Belajar Peserta Didik .}

Berdasarkan hasil data yang telah dianalisis. terlihat bahwa telah terjadinya peningkatan konsep diri peserta didik di SMK Negeri 5 Bandar Lampung dengan konseling asertivenes training. Perubahan konsep diri dapat dilihat dari hasil postest peserta didik setelah diberikannya layanan konseling asertivenes training nilai yang diproleh lebih tinggi dibandingkan dengan sebelum diberikannya layanan konseling asertivenes training atau pada saat pretest.

Selain itu. dilakukan uji pengaruh menggunakan uji t-test dan diperoleh hargat ${ }_{h i t u n g}=$ 4.004 harga ini selanjutnya dibandingkan dengan harga $t$ table dengan taraf signiffikasi 0.05 dan $n=21-1=20$ maka $t_{\text {tabel }}=2$ ternyata $t_{\text {hitung }}>t_{\text {tabel. }}$ atau $4.004>2$ maka Ha diterima dan Ho ditolak. Hal ini berarti bahwa adanya pengaruh yang signifikan antara konsep diri peserta didik dari sebelum dan setelah diberikan perlakuan berupa layanan konseling asertivenes training kepada sampel penelitian itu berarti dengan demikian terdapat perubahan pada konsep diri peserta didik. yang semulah rendah menjadi tinggi setelah diberikan layanan 
konseling asertivenes training. Berdasarkan dari hasil tindakan yang telah dilakukan tersebut dapat disimpulkan bahwa layanan konseling asertivenes training berpengaruh terhadap konsep diri peserta didik di SMK Negeri 5 Bandar Lampung.

\section{Simpulan dan Saran}

Berdasarkan hasil analisi data yang dapat diambil kesimpulan bahwa dengan perlakuan menggunakan konseling asertivenes training dapat mempengaruhi konsep diri peserta didik di SMK Negeri 5 Bandar lampung.

Hal itu terlihat dari perbandingan adanya tarap kenaikan atau perubahan sikap peserta didik sebelum dan setelah diberikan treatmen konseling asertivenes traing yang di lihat dari hasil dari hasil pretest dan posttest yang telah dilakukan. yangmana awalnya konsep diri peserta didik berada paa tarap interval sedang yaitu 14 peserta didik dari 22 peserta didik atau $63 \%$ dari $100 \%$. kemudian setelah diberikan perlakuan dengan konseling asertivenes trainin terlihat adanya kenaikan frekuansi pada tarap tinggi dengan jumlah 11 peserta didik dari 22 peserta didik atau 50\% dari $100 \%$. Jadi adanya perubahan dari kategori sedang menjadi tinggi konsep diri peserta didik.

Kemudian dari uji pengaruh dengan uji $\mathrm{t}$ diperoleh thitung $=4.004$ kemudian dibandingkan dengan $t_{\text {tabel }}=2$. Karena $t_{\text {hitung }}>t_{\text {tabel }}$. maka $H_{o}$ ditolahk dan $H_{a}$ diterima. Artinya adanya pengaruh yang signifikan trerhadap konsep diri peserta didik dari sebelum dan setelah diberikan perlakuan berupa layanan konseling asertivenes training.

Jadi secara keseluruhan penelitian ini menghasilkan kesimpulan bahwa layana konseling asertivenes training berpengaruh terhadap konsep diri peserta didik. Dan dengan hasil ini maka telah menjawab dari pertanyaan penelitian pada rumusan masalah yang diajukan yaitu terdapat atau adanya pengaruh konseling asertivenes training terhadap konsep diri peserta didik di SMK Negeri 5 Bandar Lampung.

Berdasarkan hasil pembahasan. maka penulis memberikan sarana- saran atau masukan kepada:

1. Peserta didik agar sekiranya perlu untuk senantiasa mengoptimalkan kemampuan dan kepercayaan diri agar secara tidak langsung dapat mengarahkan kepa konsep diri yang selalu fositif guna mempersiapkan diri dalam rangka menghadapi tantangan hidup dimasa mendatang agar lebih baik.

2. Guru bimbingan dan konseling agar sekiranya dapar merancang program dalam rangka memberikan layana bimbingan dan konseling secara optimal untuk membantu kesulitan- kesulitn yang dihadapi oleh peserta didik.

\section{Daftar Pustaka}

Narbuko, C., Achmadi, A. Metodologi Penelitian. Jakarta. Bumi Aksara: 2005

Departemen Pendidikan dan Kebudayaan. Kamus Besar Bahasa Indonesia. Jakarta. Balai Pustaka: 2000

Desmita. Psikologi Perkembangan Peserta Didik. Bandung. PT. Remaja Rosdakarya: 2014

Djaali. Psikologi Pendidikan. Jakarta. PT. Bumi Aksara: 2012

Prayitno, D. Mandiri Belajar SPSS. Yogyakarta. PT Buku Kita: 2009

Kurnanto, E. Konseling Kelompok. Bandung. Alfabeta: 2013

Corey, G. Teori dan Praktek Konseling Dan Psikoterapi. Bandung. PT. Refika Aditama: 2013

Agustiani, H. Psikologi Perkembangan. Bandung. PT. Refika Aditama: 2009 
Dalyono. Psikologi Pendidikan. Jakarta. Rineka Cipta: 2010

Ghufron, M.N., dan Risnawita S. Teori-Teori Psikologi. Yogyakarta. Ar-Ruzz Media: 2010

Ali, Asrori. Psikologi Remaja. Jakarta. Aksara: 2011

Damayanti, N. Buku Pintar Panduan Bimbingan Konseling. Yogyakarta. Araska: 2012

Damayanti, N. Panduan Bimbingan Konseling. Yogyakarta. Araska: 2012

Ramayulis. Ilmu Pendidikan Islam. Jakarta. Kalam Mulia: 2010

Willis, S. Konseling Individual Teori dan Praktek. Bandung. Alfabeta: 2013

Sugiyono. Metode Penelitian Pendidikan. Bandung. Alfabeta: 2013

Metode Penelitian Pendidikan Pendekatan Kuantitatif. Kualitatif. dan $R \& D$. Bandung. Alfabeta: 2009

Mustafa, Z. Mengurai Variabel Hingga Instrumentasi. Yogyakarta. Graha Ilmu: 2009

http://irvanhavefun.blogspot.co.id/2012/03/teknik-asertif-training.html diakses pada tanggal 9 februari 2016 